\title{
Phylogeny of the species of Ciconia (Aves, Ciconiidae) based on cranial osteological characteristics
}

\author{
Suely Silva Santos ${ }^{*}$, Stella Yasmin Lima Nobushige², Arthur Serejo Neves Ribeiro', \\ Francisco das Chagas Vieira Santos', Reginaldo José Donatelli3, \\ Guilherme José Bolzani De Campos Ferreira ${ }^{4}$, Anderson Guzzi ${ }^{5}$ \\ 'Federal University of Piauí, Teresina, Brazil \\ ${ }^{2}$ Castanhal Faculty, Castanhal, Brazil \\ ${ }^{3}$ São Paulo State University, Bauru, Brazil. \\ ${ }^{4}$ Federal University of Piauí, Bom Jesus, Brazil \\ ${ }^{5}$ Federal University of Piauí, Parnaiba, Brazil \\ *Corresponding author, e-mail: suelysantos.bio@gmail.com
}

\begin{abstract}
The Family Ciconiidae currently comprises 19 species distributed primarily in the tropical and sub-tropical regions around the world. Recent studies on phylogeny within the genus and families of birds provided a new opportunity for the analysis of the cranial structure in a phylogenetical context. Consequently, the aim was to describe in detail the cranial osteology of the representative species of Ciconia (C. abdimii, C. ciconia, C. episcopus, C. maguari and C. nigra), aiming to compare the characters found amongst the species that form this genus and these with the one from other members of the Family Ciconiidae and determine the family relationships amongst the species, using the methodology of phylogenetic systematic. Cranial osteology has proven to be a good tool for the cladistic analysis of the genus Ciconia, providing osteologic characters that proves the monophyly of the group. The topology of the tree obtained in the present study has revealed itself as well resolved, presenting positive perspectives to the morphologic studies of the genus. The cladogram presented corroborates the hypothesis of the monophyletic characteristic of the Ciconia, the C. ciconia being the most basal of the genus. The topology of the cladogram is: (C. ciconia ((C. nigra (C. abdimii C. episcopus)) C. maguari)). In general, Ciconia presents a specialized skull, with peculiar characteristics and different from what is observed in other groups of birds.
\end{abstract}

Keywords: Ciconiiformes. Anatomy. Sistematics.

\section{Introduction}

The Ciconiidae is formed by 19 species currently distributed in the tropical and subtropical regions around the world. Having been recognized as a family since 1901, the storks form a well-defined group highlighted by several characteristics both behavioural and morphologic: long legs with the tibiotarsus not covered by feathers; relatively short feet and with small interdigital membranes; 12 primary remiges; 12 secondary remiges; bare parts of the head; oil gland for the feathers, pectoral muscles associated to flying high altitudes; strong beak; feathering predominantly black and white; the young have two layers of fuzz; air sacs under the skin of the neck; loss of the filoplume; similar social behaviours; uro-hydrosis (behaviour of thermal regulation through defecating on the feet) (HANCOCK; KUSHLAN; KAHL, 1992).

The fossil records of the Ciconiidae dates from the beginning of the Tertiary Era, in the superior Eocene of France, but its largest propagation occurred during the Oligocene, and fossils of some current species, as members of Ciconia, are found since 140,000 years ago (DEL HOYO et al., 1992). Ciconia is found all over Eurasia, C. nigra is found in Eurasia and Southeastern Africa; C. abdimii is found in Tropical Africa; C. episcopus is found in Asia and Tropical Africa and C. maguari has its distribution restricted 
to South America (KAHL, 1971).

Considering the species of the family Ciconiidae, there is a classification of the species of the genus Ciconia in such a way that it reflects a phylogenetic proposal ((C. maguari, C. ciconia) (C. episcopus (C. nigra, C. abdimii))) (KAHL, 1971). Corroborating the previous classification, molecular data support the pairs of species C. magari, C. ciconia and abdimiiepiscopus; C. nigra with the pair C. magari, C. ciconia, $C$. boyciana based on the sequence of the cytochrome b, but C. abdimii, C. episcopus, C. stormi based on the data of hybridisation. DNA-DNA (SLIKAS, 1997).

The phylogenetic relation of $C$. nigra and its peers has little support and remains unsolved in the cladograms (SLIKAS, 1997), while C. nigra is considered the most primitive (basal) member of the genus (KAHL, 1971).

There is a classification that brings the pair C. nigra e C. ciconia closer (VERHEYEN, 1959), but this classification is not supported by the molecular data that approximate, in all the trees base on the cytochrome b, citocromo b, C. ciconia / C. boyciana and C. episcopus / C. stormi (SLIKAS, 1997); however, C. boyciana and C. stormi were not included in the hybridisation DNA-DNA. The members of each of these pairs were primarily co-specific, and only recently separated in distinct species (HANCOCK; KUSHLAN; KAHL, 1992).

Phylogeny studies within the genus and families of birds provided a new opportunity for the analysis of the cranial structure in a phylogenetic context. The skull of the birds may represent a main part in phylogenetic analyses, of new characters and anatomic evidence support strong hypothesis (LIVEZEY; ZUSI, 2007).

Having said that, the aim of this study is to describe in detail the cranial osteology of the species that represent Ciconia (C. abdimii, C. ciconia, C. episcopus, C. maguari and C. nigra), trying to compare the characters recorded among the species that form this genus and those with the other members of the family Ciconiidae, and determine the family relationships among the species, through the methodology of phylogenetic systematics.

\section{Material and Methods}

21 specimens were studied and described ( $n=21$ ) of Ciconia (C. abdimii, $C$. ciconia, C. episcopus, C. maguari and C. nigra), of the Ciconiidae. The description of the cranial osteology was comparative by using illustrations of dorsal, ventral and lateral views. The measurements of several bone structures was made using a Mitutoyo of $300 \mathrm{~mm}$ pachymeter and the measures presented were the result of three measurements of the same structure in each skull.

The nomenclature used for this description followed the Nomina Anatomica Avium (BAUMEL et al., 1993). Due to the fusion of the cranial bones of the birds, the bone delimitations of the skulls followed the description by Pascotto, Höfling and Donatelli (2006), Posso and Donatelli (2006), Méndez and Höfling (2007), Silveira and Höfling (2007) and Ladeira and Höfling (2007). Considering that most cranial bones is even and that there is bilateral symmetry, the osteological description was given in singular form (SILVA et al., 2012; GUZZl et al., 2014b; GUZZI et al., 2015a; 2015b). The classification and nomenclature of the species are the same presented by Howard and Moore (1998). The specimens which were studied in loco were primarily separated (dry skull and mandible) and are part of the collection of the National Museum of Natural History (USNM), Smithsonian Institution, Washington, DC, EUA.

The specimens used in this study were as follows: Ciconia abdimii (USNM 430528, male, Rhodesia; USNM 430455, male, Rhodesia; USNM 430456, male, Rhodesia); Ciconia nigra (USNM 291560, male, in captivity; USNM 19784, unknown gender, in captivity; USNM 555498, male, in captivity); Ciconia episcopus (USNM 430766, female, in captivity; USNM 226001, female, Celebes: Rano Lindoe; USNM 225807, unknown gender, Celebes: Toboli) Ciconia maguari (USNM 614528, female, Argentina; USNM 614527, male, Argentina; USNM 614525, male, Argentina; USNM 614526, male, Argentina; USNM 49041, male, Chile); Ciconia ciconia (USNM 605011, female, Israel, Tel Aviv; USNM 605021, female, Israel, Eliot; USNM 605015, young female, Israel, Eliot; USNM 605016, female, Israel, Eliot; USNM 605010, young female, Israel, Eliot; USNM 605012, unknown 
gender, Israel, Eliot; USNM 605010, female, Israel, Eliot).

In this study we have used the methodology of Phylogenetic Systematics, proposed by Wiley et al. (1991), where taxons considered were related based on shared derivative characters (synapomorphy). The polarization of the characters followed the methodology of the external group, proposed and discussed in Watrous and Wheeler (1981).

After describing the osteology of the species mentioned above, this study aimed to establish the primary homologies (morphologic similarities) among the taxons. Having done that, the next step was to establish the phylogenetic relations among the species of Ciconia, using characters of the cranial osteology, of the mentioned group ("in group") and of the taxons mentioned above ("out group"), trying to express the family relationships by using shared derivative characters among their members in the form of a cladogram (sensu WILEY et al., 1991). The data were analysed using manual and numerical methods, with the help of the software PAUP for Windows (FARRIS, 1988). The multi-tested characters were analysed according to the methodology described by Lipscomb (1992).

\section{Results}

Osteology

Ossacranii: The frontal region of the Ciconia ciconia (Os frontale - F, Figures. 1 - 5) occupies great part of the upper skull, around half of the total length of the skull. The interorbital width is approximately $65 \%$ of the width of the parietal region, number also observed in C. abdimii, C. nigra and C. episcopus, on the other hand, a total of approximately $50 \%$ was observed in C. maguari and about $85 \%$ for the other species. In the frontal region, the lacrimal process of the frontal (PrLF, Figures. 1 - 5) is absent in C. ciconia, although it is present in the other species. The frontal region is articulated with the nasal region rostrally through the cranial facial flexor zone (Cranial Facial Flexor Zone - ZFC Figures. 6 - 10), medially fused in Ciconia ciconia, C. nigra and C. maguari, though not fused in the other species.

The same region presents a rostral protuberance of the frontal bone (Frontal
Protuberance - PF - Figures. 1 - 5) in C. abdimii and C. episcopus, being absent in the other species; there is also a significant median rostral concavity of the frontal (Median Rostral Concavity - CRM, Figures. 1 - 5) present in C. ciconia, C. nigra and C. maguari being absent in the other species. The frontal region continues caudally with the wide parietal region and side-caudally with the strong postorbital process. The part which is close to the lacrimal has got approximately $1 / 5$ of the width of the distal part in all the species studied. The wide parietal region (the parietale - $\mathrm{P}$, Figures. 1 - 5) is limited lateral ventrally with the squamosal region through the superior temporal crest (CTS Figures. 6 - 10), conspicuous in C. ciconia and C. maguari and inconspicuous in the other species studied.

The squamosal region (the squamosum $S$ ) is limited laterodorsally by the superior temporal crest (CTS - Figures. 6 - 10) which occupies great part of the lateral portion of the skull, caudally to the process and ventral caudally by the meatus acusticus externus (MAE- Figures. 11 - 15) and by the protruding suprameatic process (Proc. suprameaticus- PrSM, Figures. 6 - 10) developed in C. ciconia and C. abdimii and presenting an intermediate condition in the other species studied.

The temporal fossa (Fossa temporalis - FT, Figures. 6 - 10) is deep in all its extension, being longer than wide rostrocaudally in all the species. The temporal fossa is limited dorsally by the superior temporal crest (CTS - Figures. 6 - 10) and ventrally by the crista nuchalis transversa, being shallow in C. nigra, deeper in C. maguari and in an intermediate condition in the other species.

The squamosal region is projected rostrally and forms the zygomatic process (Proc. zigomaticus - Prz, Figs. 6 - 10). Such process appears wide and elongated in its base and is shaped like a characteristic triangle, slightly twisted on itself, occupying approximately 60 to $70 \%$ of the distance between its origin in the skull and the jugal point in C. ciconia and C. maguari, 40 to $50 \%$ of this distance in C. abdimii, C. nigra and $C$. episcopus. The zygomatic process has the dorsal, ventral, lateral and medial facets well delimited, highlighting the local of origin of the muscles adductor mandibulae externos rostralis lateralis and medialis. 

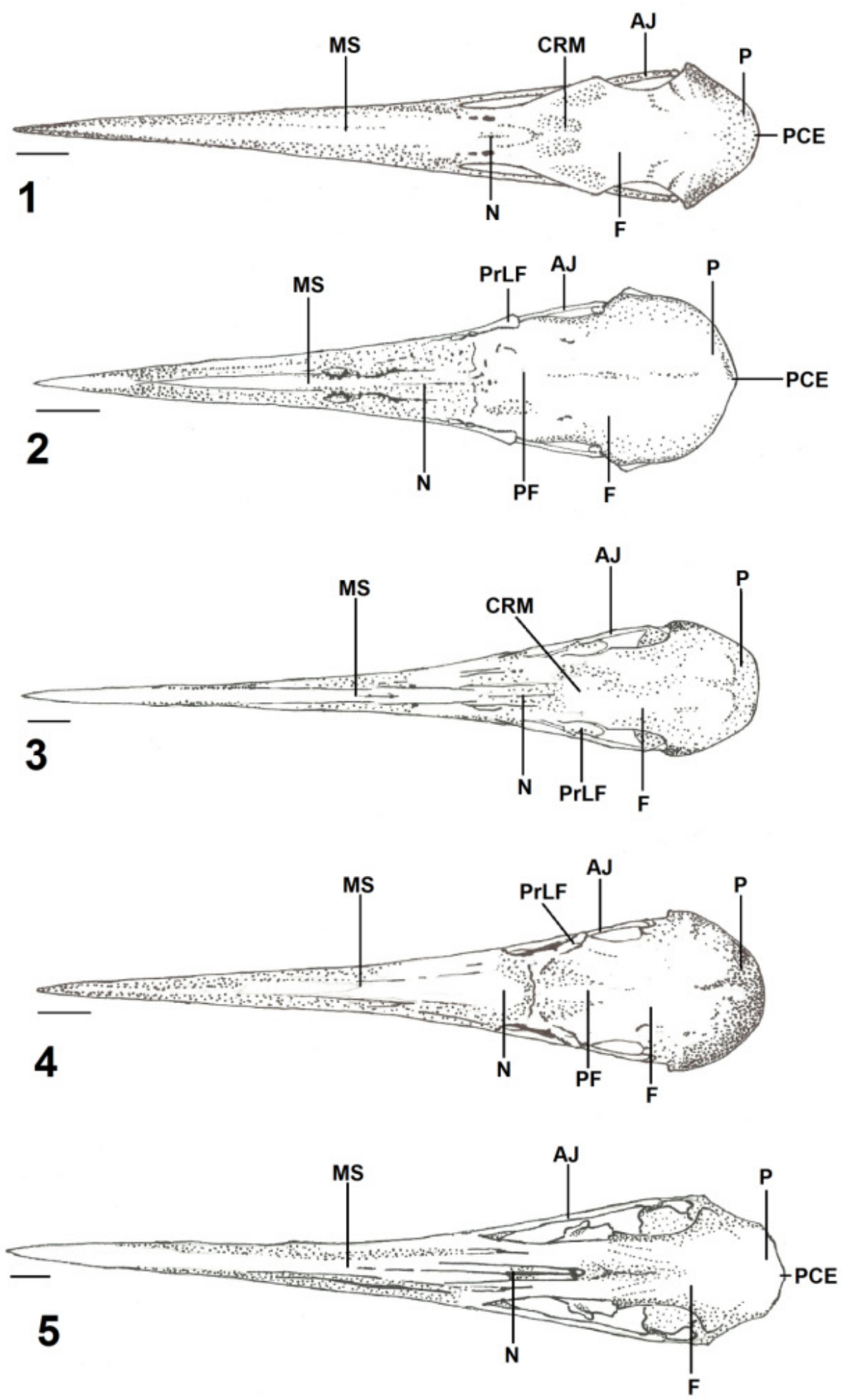

Figure 1. Dorsal view of the skull of Ciconia ciconia. Figure 2. Dorsal view of the skull of Ciconia abdimii. Figure 3. Dorsal view of the skull of Ciconia nigra. Figure 4. Dorsal view of the skull of Ciconia episcopus. Figure 5. Dorsal view of the skull of Ciconia maguari. MS: upper maxilla; N: nasal; CRM: median rostral concavity; AJ: jugal arch; F: frontal; P: parietal; PCE: cerebellar prominence; PrLF: frontal lacrimal process; PF: frontal prominence.

The squamosal region is delimited rostro medially with the latero-sphenoid and rostrodorsally with the frontal region by the post orbital process (Proc. postorbitalis- PrPO, Figures. 6-10).
Such process is long, strong and well developed, with wide base in all species of Ciconia, being short only in C. nigra. 

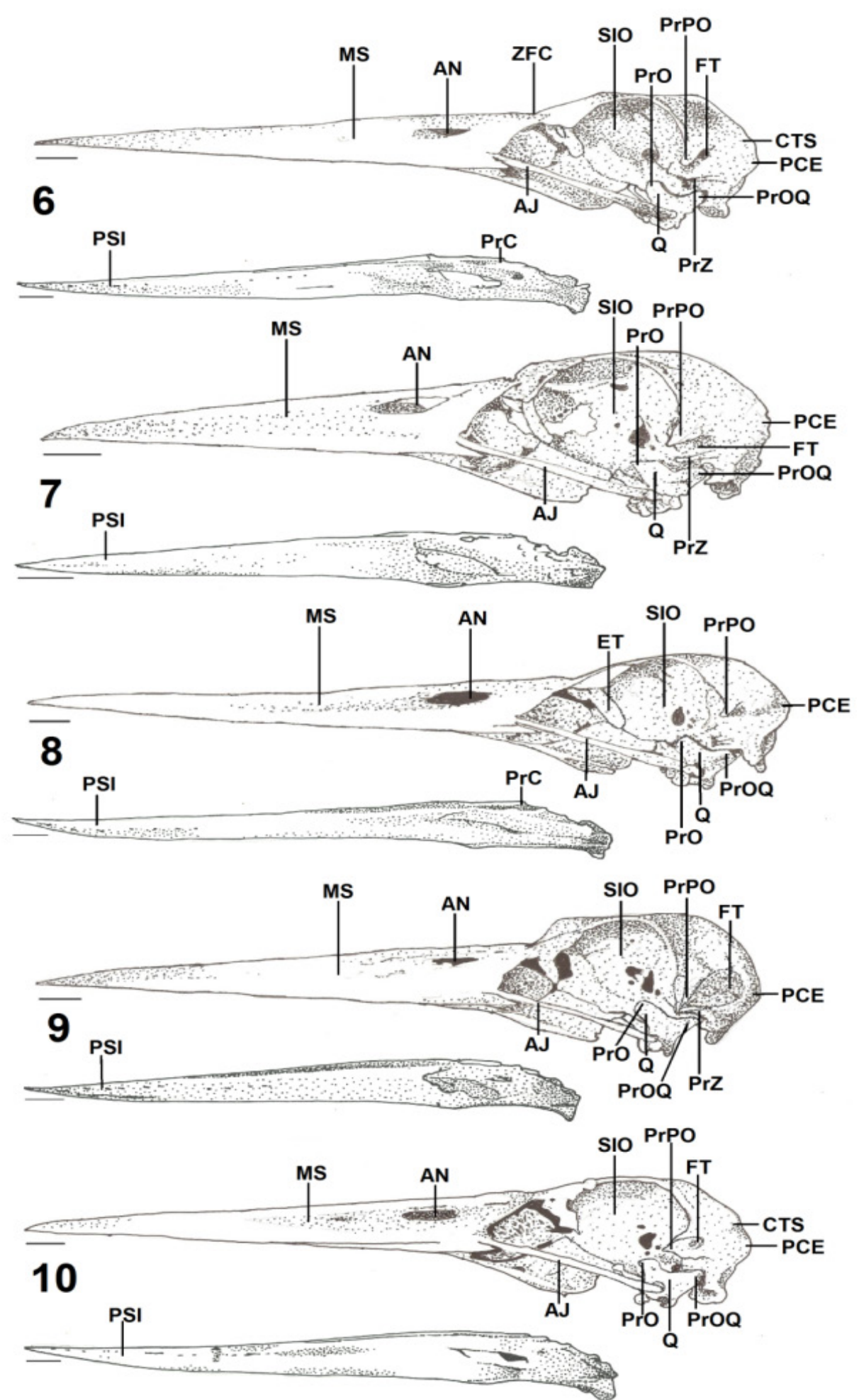

Figure 6. Lateral view of the skull and maxilla of Ciconia ciconia. Figure 7. Lateral view of skull and maxilla of Ciconia abdimii. Figure 8. Lateral view of skull and maxilla of Ciconia nigra. Figure 9. Lateral view of skull and maxilla of Ciconia episcopus. Figure 10. Lateral view of skull and maxilla of Ciconia maguari. MS: upper maxilla; AN: nasal fossa; ZFC: cranial facial flexor zone; SIO: interorbital septum; PrO: orbital process of the quadrate; PrPO: post orbital process; FT: temporal fossa; CTS: superior temporal crest; PCE: cerebellar prominence; PrOQ: optical process of the quadrate; PrZ: zygomatic process; Q: quadrate; AJ: jugal arch; PrC: coronoid process; PSI: symphysial part of maxilla; ET: ectethmoid body.

The occipital region comprises the (Os basioccipitale- BS, Figures. $11-15$ ) fused. It is supra-occipital bones (Os supraoccipitale), limited dorsal-laterally with the squamosal region exoccipital (Os exoccipitale) and basioccipital by the meatus acusticus externus and the crista 
nuchalis transversa. The region of the exoccipital bone is delimited with the tympanohyal area (Cavum tympanicum) by the evident paraoccipital process (Proc. paraoccipitalis). Its limits with the basioccipital region is marked by the presence of foramens through which nerves pass (Foramen n. glossopharingealis, n.vagie canalis $n$. hypoglossi) and by canals by which vessels pass (Ostium canalis carotici and ostium canalis ophthalmici externi) and by the proc. condylaris.

The region of the basioccipital bone protects the conspicuous occipital condyle (Condylus occipitalis-CO, Figures. 11-15) and the deep sub-condylar fossae (Fossa subcondylaris), such fossa is surrounded by two well developed basilar tubercles (Tuberculum basilare). Caudal medially one can observe the wide magnum foramen (Foramen magno- FM, Figures. 11 15). The cerebellar prominence (Cerebellar prominence - PC, Figures $1-15$ ) of the supraoccipital bone is protruding and tapered in $\mathrm{C}$. ciconia, C. maguari and not prominent in the other species.

The basioccipital region continues rostrally with the sphenoid base by the tuberculum basilare. The sphenoid base region (the basisphenoidale - BS, Figures. 11 - 15) is elongated in its base, but it is narrowed rostrally to fuse itself with the parasphenoid region. These two regions together with the basioccipital region form the greatest part of the cranial floor.

From the region of the parasphenoid bone (the parasphenoidale) we highlight the projection of the rostro-parasphenoidal (Rostrum parasphenoidale - RP, Figures. 11 - 15), that reaches about $50 \%$ of the distance from the occipital condyle and the pes pterygoidei in C. ciconia, C. abdimii and C. maguari and about $40 \%$ in the other species. The rostroparasphenoidal is articulated rostrally with the palatine and rostrolaterally with the pterygoid, is fused dorsally to the inter-orbital septum, rostrally it still touches the vomer by the facies articularis vomeralis.

The ectethmoid (the ectethmoidale - ET, Figures. $6-10$ ) appears in the shape of an "U" in C. ciconia; is smaller in C. abdimii, C. nigra, C. episcopus and C. maguari. It has got a long dorsal-ventrally distal tapered process in C. ciconia; in its fácies nasalis, it fuses rostro-laterally with the lateral-caudal facet of the frontal and lacrimal bone region. Rostro- medially it fuses with the rostral region of the inter-orbital septum.

The interorbital septum (Septum interorbitale -SIO, Figs. $6-10$ ) is delimited dorsally with the region of the frontal bone by the olfactory sulcus (Sulcus olfactorii) and the conspicuous medial orbitonasal foramen (Foramen orbitonasal mediale). It is limited rostrolaterally with the ectethmoid bone and ventrolaterally it contacts the rostroparasphenoid and to the palatine and ventrolaterally to the pterygoid in all the species studied. The laterosphenoid region is located in the caudal portion of the orbit, goes from the caudal portion of the interorbital septum up to the lateral facet of the squamosal region. In its facies temporalis, dorsolateral portion of the laterosphenoid region, it is observed laterally the proc. postorbitalis. In its facies cerebralis, medially disposed to the postorbital process, you can see a depression characteristic of the laterosphenoid region. It is also seen ventromedially to the temporal fossa the tubercle $T$ being protruding in C. ciconia and C. maguari, smaller in C. abdimii, C. nigra and C. episcopus. Ventrally to this tubercle one can observe that the foramen of the maxilla mandibular nerve is extremely wide in all the species studied. Dorsally to this foramen we see the ophthalmic nerve's one, with smaller caliber than the first.

\section{Ossa faciei}

Ossa Maxillae: The upper maxilla (MS - Figures. 1 - 10) is formed by the fusion of the premaxillary bones (the premaxillare), maxillary (the maxillare) and nasal (the nasale) and contributes with approximately 70 to $75 \%$ of the total length of the skull in C. ciconia, C. abdimii, C. nigra, C. maguari and C. episcopus. The nostrils (NA - Figures. 1 - 10) have an oval shape and are classified as the type holorhinal in all the studied species. The length of the nostrils goes until close to the cranial facial flexor zone, where it is delimited by the maxillaris process and the Os nasale dorsomedially. The lateral maxillary process of the Os nasale is wide, short and inclined. The dorsal bars of the maxillary 

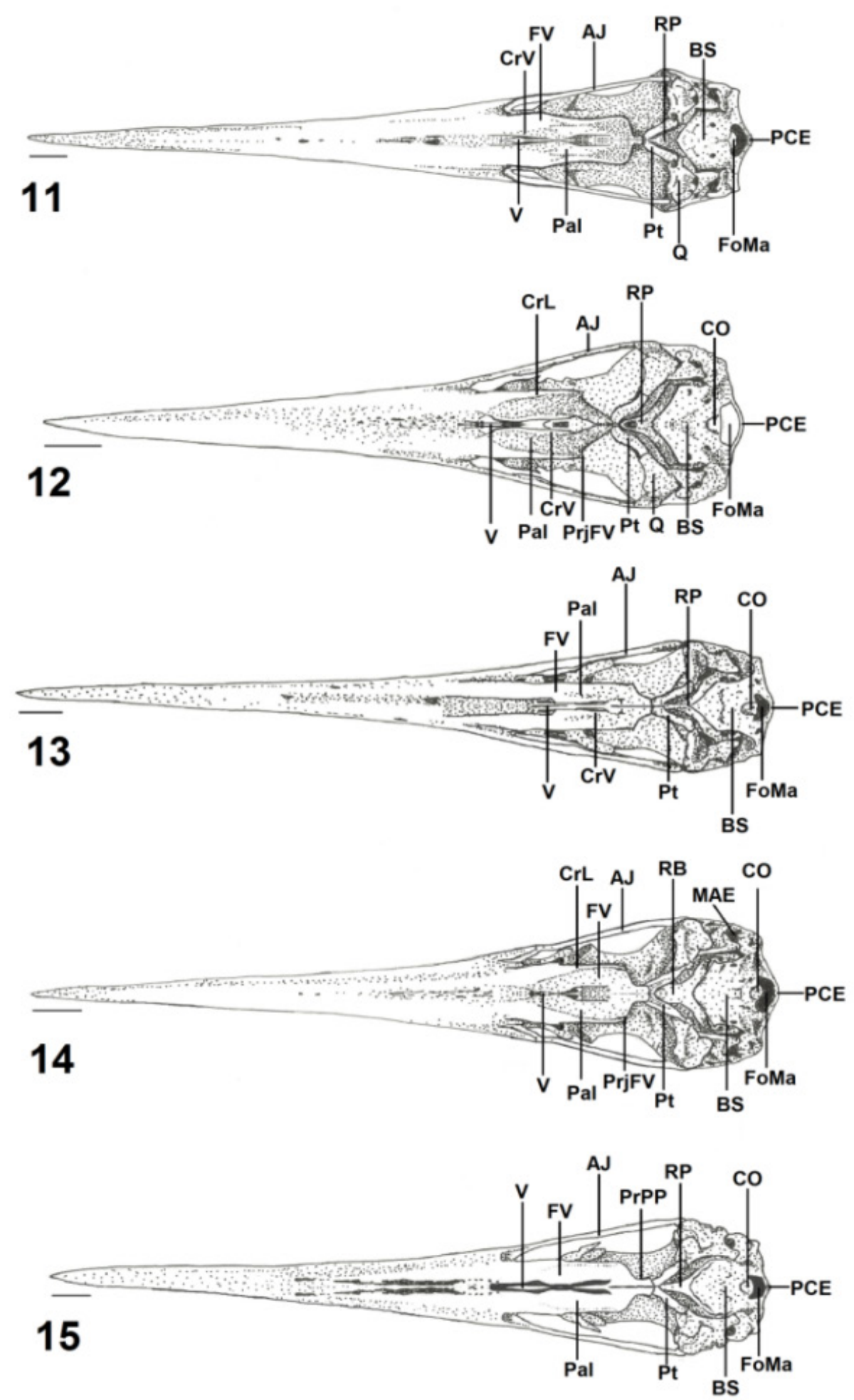

Figure 11. Ventral view of the skull of Ciconia ciconia. Figure 12. Ventral view of the skull of Ciconia abdimii. Figure 13. Ventral view of the skull of Ciconia nigra. Figure 14. Ventral view of the skull of Ciconia episcopus. Figure 15. Ventral view of the skull of Ciconia maguari. CrV: palatine ventral crest; FV: ventral fossa of the palatine; AJ: jugal arch; RP: rostro-parasphenoid; BS: basis sphenoid region; PCE: cerebellar prominence; FoMa: Magnum foramen; Q: quadrate; Pt: pterygoid; Pal: palatine; V: vomer; CrL: lateral palatine crest; CO: occipital condyle; PrjFV: caudal projection of the choanal fossa; MAE: meatusacusticus externos; PrPP: pterygoid process of the palatine.

process of the nasal, which is long, taper rostrally and delimit the dorso-caudal portion of the nostril, being of homogeneous configuration in the species considered. The cranial facial flexor zone occupies only a median portion between the frontal and nasal regions, laterally there is a 
clear fusion between these regions. The dorsal bar is found fused to the rostro-lateral face of the region of the frontal bone, the same occurs to the lateral bar.

Palati: The palate region is formed by the palatine, pterygoid and vomer bones. The maxillary process of the palatine (Proc. maxillaris) connects the palatine caudolateral lamella to the basis of the upper maxilla. This process is short and narrow in its extension in all the species analysed. The palatine caudolateral lamella (Lamella caudolateralis) of the pars lateralis is delimited medially by the prominent palatine ventral crest (Crista ventralis - CrV, Figures. 11 - 15) of the pars choanalis, by the transpalatine process and laterally by the palatine lateral crest (Crista lateralis - CrL, Figures. 11 - 15). Between the lateral and ventral crests of the palatine it is observed that there is a deep palatine fossa (Fossa ventralis - FV, Figures. 11 - 15). The palatine ventral fossa is wide and deep and forms the largest part of the palatine caudolateral lamella, being wide in C. ciconia, C. nigra and C. episcopus and narrow in the other species. The palatine ventral fossa has a projection in the caudal extremities (Projection in the caudal extremities of the palatine ventral fossa - PrjFV, Figures. 11 - 15) in C. abdimii and C. episcopus, being absent in the other species studied.

The palatine ventral crests (Crista ventralis - CrV, Figures. 11 - 15) are in the region of articulation with the parasphenoid. The articulation with the pterygoid takes place dorsolateralcaudally, by the palatine pars pterygoidea. The palatine ventral crests are long in C. ciconia and C. abdimii, and short in the other species analysed. The palatine lateral crest (Crista lateralis - CrL, Figures $11-15$ ) is long in C. ciconia, C. episcopus and C. maguari and short in the other species, delimiting the fossa choanalis. The pars choanalis is narrow and more developed whether compared to the pars lateralis described above.

The transpalatine process is absent in C. ciconia, C. nigra and C. maguari and present in the other species studied. The maxilla-palatine process is short in C. ciconia, C. episcopus and C. abdimii and long in the other species. The pterygoid process of the palatine (PrPP, Figures.
$11-15)$ is short in C. ciconia, C. abdimii, C. nigra and $C$. episcopus and long in C. maguari. The dorsal process of the pterygoid is present $C$. ciconia and C. maguari and absent in the other species studied.

The vomer ( $V$ - Figures. $11-15)$ is sharp rostrally and looks like a long blade, flattened laterolaterally and wide in C. ciconia and c. maguari and narrow in the other species, articulating caudally with the pars choanalis of the palatine and with the rostroparasphenoid by the facies articularis vomeralis.

The quadrate bone is located in a central region of the skull and interconnects the palate, the skull and the mandible, playing a fundamental role in the cranial kinetics. It presents a central corpus ossi quadrati ( $Q$ - Figures. 6 - 15) where three processes start: orbital, optical and mandibular. The orbital process of the quadrate (Proc. orbitalis - PrO, Fig. 6 - 10) is projected rostromedially in the orbit, tenuously tapering distally and ending in the shape of a bulb, being wide and longer in all the species analysed.

The optical process of the quadrate (Proc. oticus - PrOQ, Fig. 6 - 10) is widened from the corpus ossiquadrati, being developed in all the species. It articulates with the skull in two distinct places: 1) through the external optical process (Capitulum squamosum), supported in the ventro-caudal facet of the zygomatic process and 2) by the internal optical process (Capitulum oticum) that articulates with the cotyla quadrática and otici of the pro-optical and opisthotic bones, processes of homogeneous configuration amongst the species. The external section of the optical process of the quadrate is developed in all the studied species.

The mandibular process of the quadrate presents four distinct condyles: the medial condyle (Condylus medialis) - rounded in all the species analysed - the lateral condyle (Condylus lateralis) - long and stronger than the medial, articulating with the jugal bar laterally from a dorsal process - the caudal condyle (Condylus caudalis) - an extension of the lateral condyle, being fused - and the condyle pterygoideus - located medially, which articulates with the pterygoid by its quadratic articulated facet.

The caudal condyle of the quadrate is 
larger than the medial in C. ciconia, C. nigra and C. maguari, the opposite happening in the other species. The lateral condyle of the quadrate still has the cotyla quadrato jugalis (Cy), which articulates with the condyle quadraticus of the jugal bar, it is a subtle depression through which the jugal bar articulates with the quadrate, being conspicuous in these species. The medial facet of the quadrate, particularly that relative to the corpus ossiquadrati, has got a characteristic fossa, more wide than deep in all the species.

The pterygoid (Pterygoideum - PT, Figures. 11 - 15) has got a rostral expansion that widens rostro-dorsally, articulates with the palatine dorsolaterocaudally by a structure named pes pterygoidei, observed in all the species studied. In general, the pterygoid presents itself as a relatively flattened sheet and disposed obliquely in the orbit. It articulates laterocaudally with the quadrate bone by the facies articularis quadratica of the quadratic process of the pterygoid (Proc. quadraticus), developed and conspicuous in all the species. In this region of the pterygoid there is a foramen that does not totally cross this structure, in the more flattened facet latero-laterally, in the species studied. The jugal bar presents the quadratic condyle (Condylus quadraticus), which articulates with the cotyle quadratic jugal (Cotyla quadrato jugalis), in the species observed.

Ossa mandibulae: The pars symphisialis mandibulae (PSI - Figures. 6 - 10) occupies approximately 25 to $35 \%$ from the total length of the mandible in C. ciconia and from 50 to $60 \%$ of this length in the other species studied. The pars intermedia has got a well developed mandibular fenestra, however, shallow in all its extension in the species analysed; and the pars caudalis supports the muscles that move the jaws, besides being the area of articulation with the quadrate bone, important structure of the mandibular kinetics

In the dorsal region of the mandible you can see the well developed coronoid process (Proc. coronoideus - PrC, Figures. 6-10), region of the supra-angular bone (the supraangulare), at the level of the caudal portion of the mandibular fenestra. The coronoid process is conspicuous in C. nigra and inconspicuous in the other species for this matter. In the dorsocaudal region of the mandible you can observe the crista intercotylaris, seen in all the species studied.

The lateral cotyle (Cotyla lateralis) and the medial cotyle (Cotyla medialis) appear conspicuous in all the analysed species. The well-developed medial process (Proc. Medialis mandibulae) is projected dorsomedially, being wide in its base and tapered distally in all the species. The pseudotemporal tubercle pf the medial region of the mandible (Tuberculum pseudotemporale) is inconspicuous in all the species described. In the caudal region the fossa caudalis (Fossa caudalis) stands out, well developed in all the species, delimited laterally with the lateral crest, medially with the medial crest and dorsally with the crista transversa fossae.

\section{Systematics}

Polarized Characters used in the Phylogenetic Systematics

38 cranial osteological characters were found in the analysed taxons. All the characters were compared and initially the matrix has not been polarised. The polarisation took place through the comparison with the species of the external group (Table 1).

The Index of Consistency (IC) was of 0.73 , Index of Homoplasy $(\mathrm{IH})$ of 0.26 , Index of Retension of 0.67 and Index of Re-phased Retension of 0.49 . The $\mathrm{IH}$ was relatively low $(\mathrm{H}=0,26$ or $26 \%)$, what demonstrates the great consistency of data. And among the characters the ones that present the lowest IC and consequently the highest $\mathrm{IH}$, were: $2(\mathrm{IC}=0.67 ; \mathrm{IH}=0.33)$ e $7(\mathrm{IC}=0.5$; $\mathrm{IH}=0.5)$. The characters, as well as their states, are described as follows: 1. Interorbital width [ic $=1.000$; (0. until $50 \%$ of the width of the parietal region; 1. From 60 to $70 \%$ from the width of the parietal region)]. 2. Cranial facial flexor zone [ic = 0.500; (0. Medially fused; 1 . Not medially fused)]. 3. Rostral Prominence of the frontal [ic = 1.000; (0. absent; 1. present)]. 4. Median Rostral Concavity [ic $=0.500$; (0. present; 1 . absent)]. 5. Postorbital process [ic $=0.500$; 10 . long (more than $25 \%$ of the basal insertion to the jugal bar); 1. short (less than $25 \%$ of the basal insertion to the jugal bar)]. 6. Suprameatic process [ic $=0.500$; (0. prominent; 1. intermediate)]. 7. Temporal 
Table 1. Polarised Matrix of the Characters.

\begin{tabular}{|c|c|c|c|c|c|c|c|}
\hline Species & $\begin{array}{l}\text { Anastomus } \\
\text { lamelligerus }\end{array}$ & $\begin{array}{l}\text { Anastomus } \\
\text { oscitans }\end{array}$ & $\begin{array}{l}\text { Ciconia } \\
\text { ciconia }\end{array}$ & $\begin{array}{l}\text { Ciconia } \\
\text { nigra }\end{array}$ & $\begin{array}{l}\text { Ciconia } \\
\text { abdimii }\end{array}$ & $\begin{array}{l}\text { Ciconia } \\
\text { maguari }\end{array}$ & $\begin{array}{l}\text { Ciconia } \\
\text { episcopus }\end{array}$ \\
\hline 1 & 0 & 0 & 0 & 0 & 0 & 1 & 0 \\
\hline 2 & 0 & 1 & 0 & 0 & 1 & 0 & 1 \\
\hline 3 & 0 & 0 & 0 & 0 & 1 & 0 & 1 \\
\hline 4 & 0 & 1 & 0 & 0 & 1 & 0 & 1 \\
\hline 5 & 0 & 0 & 1 & 0 & 1 & 1 & 1 \\
\hline 6 & 0 & 0 & 0 & 1 & 0 & 1 & 1 \\
\hline 7 & 1 & 1 & 1 & 2 & 1 & 0 & 1 \\
\hline 8 & 0 & 0 & 1 & 0 & 0 & 1 & 0 \\
\hline 9 & 0 & 0 & 0 & 1 & 0 & 0 & 1 \\
\hline 10 & 0 & 0 & 0 & 1 & 1 & 0 & 1 \\
\hline 11 & 0 & 0 & 2 & 1 & 1 & 1 & 1 \\
\hline 12 & 0 & 0 & 0 & 1 & 1 & 1 & 1 \\
\hline 13 & 0 & 0 & 0 & 1 & 0 & 1 & 0 \\
\hline 14 & 0 & 0 & 0 & 1 & 1 & 0 & 0 \\
\hline 15 & 1 & 1 & 1 & 1 & 1 & 2 & 1 \\
\hline 16 & 0 & 0 & 0 & 1 & 1 & 0 & 0 \\
\hline 17 & 0 & 0 & 0 & 0 & 1 & 1 & 0 \\
\hline 18 & 0 & 0 & 0 & 1 & 1 & 0 & 1 \\
\hline 19 & 0 & 0 & 0 & 1 & 1 & 0 & 1 \\
\hline 20 & 0 & 0 & 1 & 1 & 1 & 1 & 1 \\
\hline 21 & 0 & 0 & 0 & 0 & 0 & 0 & 0 \\
\hline 22 & 0 & 0 & 0 & 0 & 0 & 0 & 0 \\
\hline 23 & 0 & 0 & 0 & 0 & 0 & 0 & 0 \\
\hline 24 & 0 & 0 & 0 & 0 & 1 & 0 & 1 \\
\hline 25 & 0 & 0 & 0 & 1 & 1 & 0 & 1 \\
\hline 26 & 0 & 0 & 0 & 1 & 1 & 0 & 1 \\
\hline 27 & 0 & 0 & 0 & 0 & 0 & 0 & 1 \\
\hline 28 & 1 & 1 & 2 & 1 & 1 & 1 & 1 \\
\hline 29 & 0 & 0 & 1 & 0 & 1 & 1 & 1 \\
\hline 30 & 0 & 0 & 1 & 1 & 1 & 1 & 1 \\
\hline 31 & 0 & 0 & 0 & 0 & 0 & 0 & 0 \\
\hline 32 & 0 & 0 & 0 & 0 & 0 & 0 & 0 \\
\hline 33 & 0 & 0 & 1 & 1 & 1 & 1 & 1 \\
\hline 34 & 0 & 0 & 1 & 1 & 0 & 1 & 0 \\
\hline 35 & 0 & 0 & 0 & 0 & 1 & 0 & 1 \\
\hline 36 & 0 & 0 & 0 & 0 & 0 & 0 & 0 \\
\hline 37 & 0 & 0 & 1 & 0 & 0 & 0 & 0 \\
\hline 38 & 0 & 0 & 0 & 0 & 0 & 0 & 0 \\
\hline
\end{tabular}

Fossa [ic = 1.000; (0. deep; 1 . intermediate; 2 . shallow)]. 8. Zygomatic process [ic $=0.500 ;(0$. from 60 to $70 \%$ of the distance between its origin and the jugal bar; 1 . Approximately $50 \%$ of the distance between its origin and the jugal bar)]. 9. Parasphenoid rostro [ic $=0.500$; (0. until $40 \%$ of the distance from the occipital condyle to the articulation with the pterygoid; 1 . about $50 \%$ of the distance from the occipital condyle to the articulation with the pterygoid)]. 10. Tubercle $\mathrm{T}$ [ic = 1.000; (0. developed (from its origin to the latero-sphenoid); 1. reduced (from its origin to the latero-sphenoid)]. 11. Ectethmoid body [ic = 1.000; (0. vestigial (in the shape of a tubercle);
1. reduced (from its origin to the jugal bar); 2 . developed (from its origin to the jugal bar)]. 12. Ectethmoid process [ic $=1.000$; 10 . long (from its origin to the jugal bar); 1. reduced (from its origin to the jugal bar). 13. Maxillopalatine process [ic =0.500; (0. short; 1. long)]. 14. Lateral palatine crest [ic $=0.500 ;$ (0. long; 1.short)]. 15. Pterygoid process of the palatine [ic $=1.000$; (1. short (the articulation occurs in the short projection of the palatine); 2. Long (the articulation occurs in the long projection of the palatine)]. 16. Ventral palatine Crest [ic $=0.500$; 10 . short (compared to the PrM); 1. long (compared to the PrM)]. 17. Ventral Palatine Fossa $[\mathrm{ic}=0.500$; (0. wide; 
1. narrow)]. 18. Vomer [ic = 1.000; (0. narrow; 1 . wide)]. 19. Dorsal process of the Pterygoid [ic $=$ 1.000; (0. present; 1. absent)]. 20. Orbital process of the Quadrate [ic = 1.000; (0. long (from its origin to the interorbital septum); 1 . short (from its origin to the interorbital septum)]. 21. Optical process of the Quadrate (0. present and developed). 22. Squamosal capitulum of the optical process of the quadrate (0. Present and developed). 23. Optical capitulum of the optical process of the quadrate (0. present and developed). 24. Relation condyle medial $X$ caudal of the quadrate $[$ ic $=1.000 ; \quad$ ( . caudal $<$ medial; 1 . caudal > medial )]. 25. Superior Temporal crest [ic $=1.000 ;$ (0. conspicuous; 1. inconspicuous)]. 26 . Cerebellar Prominence [ic $=1.000$; (0. prominent: 1. not prominent)]. 27. upper Maxilla [ic = 1.000; (0. More than $70 \%$ of the total length of the skull; 1. Up to $65 \%$ of the total length of the skull)]. 28. Par symphysialis mandibulae [ic $=1.000 ;(1.15$ -
$35 \%$ of the total length of the mandible; 2 . More than $35 \%$ of the total length of the mandible)]. 29. Coronoid process [ic $=0.500$; (0. inconspicuous; 1 . Conspicuous)]. 30. intercotilaris crest [ic $=1.000$; (0. Conspicuous; 1. inconspicuous)]. 31. Medial process of the mandible (0. Dorso-medially disposed). 32. Pseudotemporal Tubercle (0. present). 33. Emargination of the rostrodorsal edge of the postorbital process [ic $=1.000$; $(0$. absent; 1. present). 34. Transpalatine process [ic $=0.500$; (0. absent; 1. Present)]. 35. Caudal expansion of the Choanal Fossa [ic $=1.000 ;(0$. absent; 1. present)]. 36. K process of the mandible (0. Present and developed). 37. Lacrimal bone [ic = 1.000; (0. Not fused to the frontal; 1 . Fused to the frontal )]. 38. Nasal aperture (0. Present and developed).

\section{Discussion}

The interorbital diameter was codified

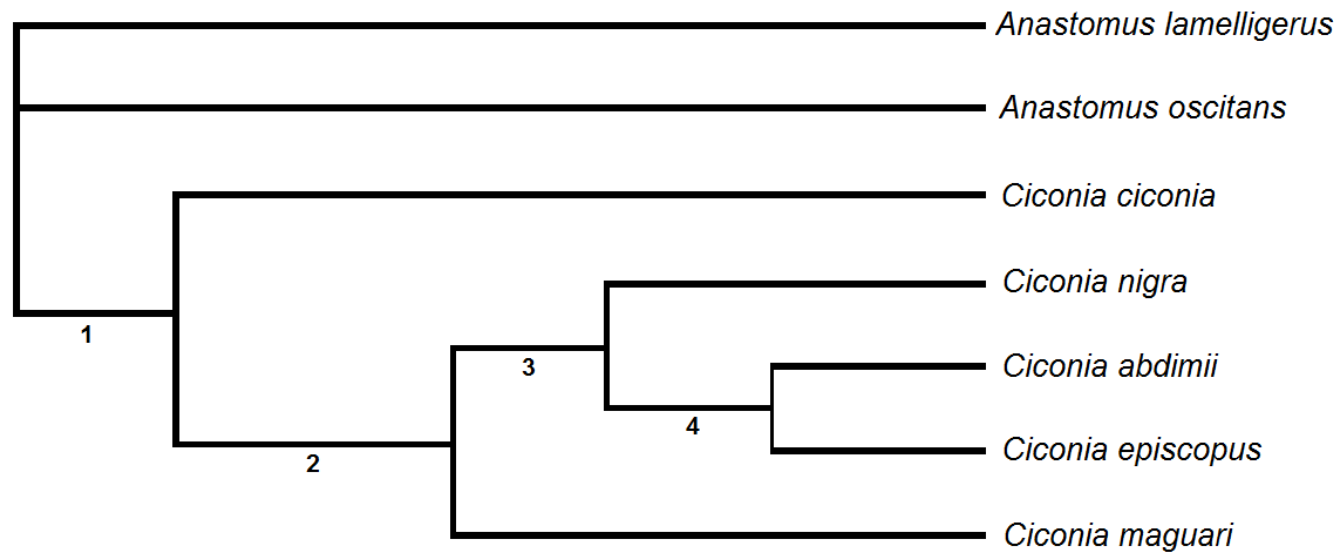

Figure 16. Phylogenetic relationship amongst the species of Ciconia, based on cranial osteological characters, applied in the cladistic analysis. Index of Consistency (IC): 0.73; Index of Homoplasy (IH): 0.26; Index of retension (IR): 0.67 ; Index of re-phased retension (RC): 0.49; (1-5): fields to indicate synapomorphy and classification.

in two states, the largest being present in C. maguari, while in C. ciconia, C. nigra, C. episcopus and C. abdimii there was a reduction in the interorbital diameter. Such reduction is related to the increase of the range of the area of sight. This increase of the overlapping of the field of sight might result from an increase of the hunting ability, because the binocular vision of some birds requires a reduction of the preorbital region, fact observed in the species $C$. ciconia, C. nigra, C. episcopus and C. abdimii (PASCOTTO; HÖFLING; DONATELLI, 2006; SILVA ef al., 2012; GUZZl et al., 2015b).
C. abdimii and C. episcopus (internal 4), share the flexor cranial facial zone not funded medially (character 2, condition 1); present rostral prominence (character 3, condition 1); absent median rostral concavity (character 4, condition 0); relation medial $x$ caudal condyle of the quadrate caudal > medial (character 24, condition 1); caudal expansion of the present choanal fossa (character 35, condition 1); short maxillopalatine process (character 13, condition 0 ) and absent transpalatine process (character 34, condition 0).

The cranial facial flexor zone is known 
as an area of constriction of the nasal bones caudally, and responsible for the major part of the cranial kinetics (LIVEZEY; ZUSI, 2007). In the species C. ciconia, C. nigra and C. maguari this region is fused medially, while in C. abdimii and C. episcopus there is a clear articulation between the frontal and the nasal. The discussion of this character requires an analysis of the cranial kinetics of the species of birds studied, considering that both are closely related, because the movements of opening and closing of the beak depend on the conformation and position of the structures that form it. All the studied specimens present the holorhinal condition of the nostril, and in general, present narrow nostrils, premaxillary strongly fused to the nasal, and both entirely calcified. The terms holorhinal and schizorhynous emphasize the functional differences between the two types and all the species analysed in the present study show prokinetics resulting from the holorhinal condition of the nostril (LIVEZEY; ZUSI, 2007).

AsobservedinMycteria, family Ciconiidae (GUZZl et. al., 2014a), the temporal fossa is longer than wide in all the species of Ciconia, being deeper in C. ciconia, C. abdimii and C. episcopus, while in C. maguari it is deeper and in C. nigra shallow. The pattern of the temporal fossa of the Ciconiidae differs from the pattern found in the Cuculiformes (POSSO; DONATELLI, 2006), in the Alcedinidae (MÉNDEZ; HÖFLING, 2007) and Falconidae (GUZZl et al., 2015a; 2015b), because in the species of these groups the temporal fossa is divided into two portions, as well as has the postorbital process less developed. In some species of Tinamidae, the temporal fossa during its ontogenetic development is formed with the contribution of the frontal and parietal bones. This development was observed in diaphanized young and adult individuals, what contributes for the comprehension of the positions and the limits of each structure, orienting the determination of homologies (SILVEIRA; HÖFLING, 2007).

C. ciconia, C. maguari, C. nigra and the pair C. abdimii and C. episcopus (internal 1) share the characters: present transpalatine process (character 34, condition 1); present emargination of the retrodorsal edge of the postorbital process (character 33, condition 1); conspicuous intercotilaris crest (character 30, condition 0); conspicuous coronoid process (character 29, condition 1); short orbital process of the quadrate (character 20, condition 1); reduced ectethmoid body (character 11, condition 1); zygomatic process about $50 \%$ of the distance between its origin and the jugal bar (character 8, condition 1) and short postorbital process (character 5 , condition 1 ).

The postorbital process in C. nigra is short, and long in the other species observed. In the Galliformes there is a connection in the temporal fossa, formed by the postorbital process and a calcified aponeurosis located in the rostral extremity of the zygomatic process, indicating that the larger the deposit of calcium salts, the larger the fusion of these structures in the adults will be, contrasting with the absence of this fusion in the young ones (LIVEZEY; ZUSI, 2007).

The presence of the postorbital ligament, allied to the action of the quadrate and the muscles that move the maxilla, enables the opening of the lower and upper mandibles in only one movement. The intricate system of levers may have redefined the muscular action, providing more speed and synchrony, this way increasing the success in the behaviour of foraging of the species that have it (LIVEZEY; ZUSI, 2007). In all the observed species the lacrimal is found absent and the ectethmoid developed only in C. ciconia, being reduced in the other ones.

C. maguari, C. nigra and the pair C. abdimii and C. episcopus (internal 2) share the following characters: intermediate suprameatic process (character 6, condition 1); reduced process of the ectethmoid (character 12, condition 1); long maxillopalatine process (character 13, condition 1).

The palatine acts as an area of origin for several muscles and ligaments, being essential in the cranial kinetics to transmit strength and direct the movements of the mandible to the upper maxilla. The shape and thickness of the palatine are associated to the size and the strength of the upper maxilla, as well as the resistance of the musculature (BOCK, 1966). As in the present study, five characters were considered in the Mycteria, which are directly related to 
the palatine; maxillopalatine process; lateral palatine crest; pterygoid process of the palatine: ventral palatine crest and ventral palatine fossa, demonstrating the importance of this structure and that its different conditions are used to group different taxons of birds (GUZZI et. al., 2014a).

C. nigra and the pair C. abdimii and C. episcopus (internal 3) share the parasphenoid rostro in approximately $50 \%$ of the distance from the occipital condyle to the articulation of the pterygoid (character 9, condition 1); reduced Tubercle T (character 10, condition 1); short lateral palatine crest (character 14, condition 1); long ventral palatine crest (character 16, condition 1); wide vomer (character 18, condition 1): inconspicuous superior temporal crest (character 25, condition 1), cerebellar prominence not prominent (character 26, condition 1); zygomatic process from 60 to $70 \%$ of the distance between its origin and the jugal bar (character 19, condition $1)$.

The vomer is reduced and tapered rostrocaudally in all the analysed species, the same pattern is found in the Cuculiformes of the New World (POSSO; DONATELLI, 2006) and in the species of Bucconidae (LADEIRA; HÖFLING, 2007). The vomer bone is considered an important structure in the systematic point of view and its variations are considered informative, these variations were observed among the species of Nyctibiidae contributing for a future phylogenetic analysis of the family (COSTA and DONATELLI, 2009).

The cladogram presented proposes the hypothesis of monophyletism for the species of Ciconia, introducing C. abdimii, as a sister group to $C$. episcopus (internal 4), and within the internal 1 we can observe bigger proximity among Ciconia abdimii; Ciconia episcopus; Ciconia maguari; Ciconia nigra; both sister groups of Ciconia ciconia; (internal 1). While Anastomus lamelligerus; Anastomus oscitans, are considered external group for this study.

While this study shows C. ciconia as the most basal taxon of the group, nevertheless, another study with osteological and morphological characters pointed C. nigra as external group to the pair C. abdimii and C. ciconia (DE PETRI; MAYR, 2014). This might be related to the characters used for the separations of the clades in the second study being, besides the long postorbital process, the rostral portion of the angular bill and the curved shape of the bill, characters subject to adaptive convergence, in turn, this study is based on the characters: interorbital width, cranial facial flexor zone, rostral prominence of the frontal, median rostral concavity, post orbital process, suprameatic process, temporal fossa, zygomatic process, rostroparasphenoid, tubercle $T$, body of ectethmoid, ectethmoid process, maxillopalatine process, lateral palatine crest, pterygoid process of the palatine, ventral palatine crest, ventral palatine fossa, vomer, dorsal process of the pterygoid, orbital process of the quadrate, relation medial $x$ caudal condyle, superior temporal crest, cerebellar prominence, upper maxilla, pair symphysialis mandibulae, coronoid process, intercotilaris crest, emargination of the rostrodorsal edge of the postorbital process, transpalatine process, caudal expansion of the choanal fossa, lacrimal bone, which are strong indicators of phylogenetic proximity.

Data of phenetic analysis through osteological characters does not relation Anastomus of any other genus, but it also ensures its monophyly, as observed by the present study, having as synapomorphies the characters 11 (body of the ectethmoid, condition 0, vestigial) and 30 (intercotilaris crest of the mandible, condition 1, inconspicuous) (VERHEYEN, 1959). The present study raised osteological characters that support the monophyly of Ciconia. Based on molecular data the polytomy of Ciconia may reflect a rapid process of speciation, because the trees of consensus have their branches collapsed (generating polytomies), when the trees from where they came (hybridisation DNA-DNA and analysis of cytochrome b), have the branches short (SLIKAS, 1997).

Through the hybridisation DNA-DNA there is a proximity between Ciconia episcopus and C. abdimii, and both from C. nigra, corroborating the data obtained in this study. As well as there is a proximity between C. maguari and C. ciconia, while in this study these two species are found more distant (SLIKAS, 1997). The phylogenetic relationships of the species of Ciconia proposed in 
this study corroborate in great part the hypothesis of Kahl (1971) and Slikas (1997), mainly regarding the phylogenetic position of $C$. episcopus but in both cases the cited genus is considered monophyletic.

There is a proximity between Ciconia episcopus and C. abdimii, based on behavioural characters related to mating, what confirms the observed. The monophyly of Ciconia is related in characters of external morphology, as feather colouring, shape of the beak, or through behavioural characters of nest construction using feathers from the adults. These characteristics may not be homologous, but come from a process of evolutionary convergence (KAHL, 1971). The behaviour of Ciconia maguari and C. ciconia, has got a close phylogenetic relationship between these two species, mainly regarding the mating behaviour, nesting and parental care, besides the ontogenetic development of the Spawn (THOMAS, 1988). Slikas (1997) approximated C. episcopus of C. abdimii, and these two of $C$. nigra, what corroborates the topography of the cladogram proposed by this study.

\section{Conclusion}

The cranial osteology has proven to be a useful tool for the cladistics analysis of the genus Ciconia. In general, Ciconia presents a specialised skull, with peculiar and distinct characteristics from what was observed in other groups of birds. Although the relation between the shape of a structure and its function may not be completely established, many of the adaptations of the skull of the studied species are clearly related to their lifestyles and behaviour. The modifications and adaptations in the skull of these species may be basically connected to the reduction of the interorbital diameter that enables an increase of the field of vision, to the pro-kinetics of the skull that gives resistance to the upper maxilla.

The topology of the tree obtained in the present study has proven to be well resolved, revealing positive perspectives to the morphological studies of the genus Ciconia, proposing the monophyly of the group.

\section{Referências}

BAUMEL, J.; KING, A. S.; LUCAS, A. M.; BREAZILE, J. E.; EVANS, H. E. Nomina anatomica avium.
London: Academic Press, 1993. 637p.

BOCK, W. J. An approach to the functional analysis of bill shape. Auk, Washington, v. 83, n. 1, p.10-52, jan. 1966.

COSTA, T. V. V.; DONATELLI, R. J. Osteologia craniana de Nyctibiidae (Aves, Caprimulgiformes). Papéis Avulsos de Zoologia, v. 49, n. 21, p. 257-275, 2009.

DE PIETRI, V. L.; MAYR, G. The phylogenetic relationships of the early miocene stork Grallavis edwadsi, with comments on the interrelationships of living Ciconiidae (Aves). Zoologica Scripta, v.46, n. 6, 576-585, nov. 2014.

DEL HOYO, J.; ELIOTT, A.; SARGATAL, J. (Eds.). Handbook of the birds of the world. Barcelona: Lynx, 1992. 638p.

FARRIS, J. S. Hennig86 version 1.5. Computer program distributed by J. S. FARRIS, Port Jefferson station, New York, 1988.

GUZZI , A.; CASTRO, J. M. N.; MARTINS-JUNIOR R. N. C.; DONATELLI, R. J.; SOARES, L. M. S.; FERREIRA, G. J. B. C. Osteologia craniana comparada de Caracara cheriway (Jacquin, 1784) e Caracara plancus (Miller, 1777) (AVES: FALCONIDAE). Ciência e Natura, v. 37 n. 2, p. 219-230, mai./ago. 2015b.

GUZZI , A.; NASCIMENTO, M. S.; LIMA, S. P.; SANTOS S. S.; DONATELLI, R. J. Osteologia craniana e aspectos evolutivos de Mycteria (AVES: CICONIIDAE). Revista Nordestina de Biologia, v. 23, n. 1. p. 85-102, 2014a.

GUZZI , A.; SANTOS, A. M.; SANTOS, J. D.; DONATELLI, R. J.; FERREIRA, G. J. B. C. Principais caracteres da osteologia craniana de Milvago chimango (Vieillot, 1816) e Milvago chimachima (Vieillot, 1816) (Aves: Falconidae). Biotemas, v. 28 n. 3, p. 107-119, set. $2015 a$.

GUZZI, A.; SANTOS, F. C. V.; FERREIRA, G. J. B. C.; DONATELLI, R. J. Comparative analysis of the cranial osteology and evolutionary traits of Micrastur gilvicollis, Micrastur ruficollis and Micrastur semitorquatus (Aves: Falconiformes). Revista Nordestina de Zoologia, v. 8, n. 1, p. 70 88, jan/jun. 2014b.

HANCOCK, J. A.; KUSHLAN, J.; KAHL, M. P. Storks, ibises, and spoonbills of the world. San Diego: Academic Press, 1992. 385p.

HOWARD, R.; MOORE, A. A complete checklist of the birds of the world. 2. ed. San Diego: Academic Press, 1998. 630p.

KAHL, M. P. Social behavior and taxonomic relationships of the storks. Living Bird, v. 10, p. 151170, 1971. 
LADEIRA, L. M. C. B; HÖFLING, E. Cranial osteology of Bucconidae. Boletim Museu Paraense Emílio Goeldi, Ciências Naturais. v. 2, n. 1, p. 117-153, jan./abr. 2007.

LIPSCOMB, D. L. Parsimony, homology and the analysis of multistate characters. Cladistics, v.8, n. 4, p 45-65, mar. 1992

LIVEZEY, B. C.; ZUSI, R. L. Higher-order phylogenetics of modern Aves based on comparative anatomy. II Analysis and discussion. Zoological Journal of the Linnean Society, v.149, p. 1-95, jan. 2007.

MÉNDEZ, A.; HOFLING, E. Osteologia craniana de Cerylinae (Coraciiformes: Alcedinidae). Boletim Museu Paraense Emilio Goeldi, Ciências Naturais, v. 2, n. 1, p. 155-182, jan./abr. 2007.

PASCOTTO, M. C.; HÖFLING, E; DONATELLI, R. J. Cranial Osteology of Coraciiformes (Aves). Revista Brasileira de Zoologia, v.23, n.3, p. 841864 , set. 2006.

POSSO, S. R.; DONATELLI, R. J. Análise filogenética e implicações sistemáticas e evolutivas nos Cuculiformes (Aves) com base na osteologia, comportamento e ecologia. Revista Brasileira de Zoologia, v. 23, n. 3, p. 608-629, set. 2006.

SILVA, A. G.;FERREIRA， G. J. B.; DONATELLI, R. J.; GUZZI A. Osteologia Craniana de Micrastur semitorquatus Vieillot, 1817 (Falconiformes: Falconidae). Comunicata Scientiae, v. 3, n. 1, p. 64-71, jan./mar. 2012.

SILVEIRA, F. L.; HÖFLING, E. Cranial osteology in Tinamidae (Birds: Tinamiformes), with systematic considerations. Boletim Museu Paraense Emílio Goeldi: Ciências Naturais. v. 2, n. 1, p. 15-54, jan./ abr. 2007.

SLIKAS, B. 1997. Phylogeny of the avian family Coniidae (Storks) based on Cytochrome b sequences and DNA-DNA hybridization distances. Molecular Phylogenetics and Evolution, v.8, n.3, p.275-300, dez. 1997.

THOMAS, B. T. A comparison of the Maguari Stork, Ciconia maguari, with the White Stork, Ciconia ciconia. Le Gerfaut, v.78, p.113-119, 1988.

VERHEYEN, R. Contribution a l'anatomie et a la systématique de base des Ciconiiformes (Parker 1868). Bulletin de I'Institut Royal des Sciences Naturelles de Belgique, v. 35, n. 24, 1959.

WATROUS, L. E.; WHEELER, Q.D. The out-group comparison method of character analysis. Systematic Zoology, v.30, n. 1, p.1-11, mar.1981.

WILEY, E. O., SIEGEL-CAUSEY D.; BROOKS, D. R.; FUNK, V. A. The compleat cladist: a primer of phylogenetic procedures. Lawrence: The University of Kansas/Museum of Natural History,
(Special Publication, 19), 1991. 